\title{
Yield and Yield Attributes of Soybean (Glycine max L.) as affected by Seed Priming
}

\author{
Rupinder Kaur Jassal*, Harmeet Singh and Jasjit Singh Kang
}

Department of Agronomy, Punjab Agricultural University, Ludhiana (141004), Punjab, India

\author{
*Corresponding author
}

A B S T R A C T

\begin{tabular}{|l|}
\hline Ke y w or d s \\
$\begin{array}{l}\text { Soybean (Glycine } \\
\text { max L.), Yield, } \\
\text { Treatments. }\end{array}$ \\
\hline Article Info \\
\hline $\begin{array}{l}\text { Accepted: } \\
\text { 28 October } 2017 \\
\text { Available Online: } \\
10 \text { December } 2017\end{array}$ \\
\hline
\end{tabular}

The field experiment was conducted to study the effects of different priming treatments on yield and yield attributing characters of soybean crop (SL-958). The seed priming treatments comprised of twelve priming treatments i.e. control or non-primed seeds, hydro or water primed seeds, seeds treated with solution of $\mathrm{KNO}_{3}(0.5$ and $1.0 \%), \mathrm{KH}_{2} \mathrm{PO}_{4}(0.5$ and $1.0 \%), \mathrm{KCl}(50$ and $100 \mathrm{ppm}), \mathrm{GA}_{3}(50$ and $100 \mathrm{ppm}$ ) and cytokinin (50 and $100 \mathrm{ppm})$ for 2 hour priming duration. Results revealed that yield attribute like number of pods per plant was recorded significantly higher with treatment $100 \mathrm{ppm} \mathrm{GA}$ whereas other yield attribute like seeds per pod and 100- seed weight recorded non-significant results with different priming treatments. The pooled seed yield shows increase by $30.6 \%$ with 100 ppm $\mathrm{GA}_{3}$ than control.

\section{Introduction}

Poor crop establishment is the main constraint in the growth and production of soybean and high yields can be associated with early vigour. Unfavourable environmental conditions are the major cause of poor seed establishment and low crop yield. However rapid germination of seedlings could emerge and produce deep roots before the upper layers of the soil are dried and crusted, which may result better crop establishment and higher crop yield (Ashraf et al., 2005). In northern India, soybean is sown in first fortnight of June when the soil temperature is at its maximum and rainfall is also occurring in this season. So after rainfall the soil conditions became unfit for soybean emergence and cause rotting of seeds inside the soil due to high temperature of soil. One way for achieving good crop stand, enhancing capacity of legumes to fix more atmospheric nitrogen and getting more benefit from low fertile soils is seed priming which is a technique in which germination processes begin but radicle emergence does not occur.

The concept of seed priming was proposed by Hedecker in 1973. It is a basic and ease hydration process in seeds in which seeds are partially hydrated to a point where its premetabolic activities has started to begin without actual germination of the seeds. Seed priming found effective for pulses that is yields of crops were increased considerably by priming seeds before sowing (Musa et al., 
2001, Rashid et al., 2004 and Harris et al., 2004). In addition to better establishment, primed crops grew more vigorously, flowered earlier and yielded higher (Farooq et al., 2008). It has also been reported that seed priming improves emergence, stand establishment, tillering, allometry, grain and straw yields, and harvest index.

\section{Materials and Methods}

This study was conducted at the Punjab Agricultural University, Ludhiana $\left(30^{\circ} 56^{\prime} \mathrm{N}\right.$, $75^{\circ} 48^{\prime} \mathrm{E}$ and $247 \mathrm{~m}$ above mean sea level), Punjab during 2015-2016. Seeds of soybean variety SL-958 were used for seed priming treatments. Solution of $\mathrm{KNO}_{3}(0.5$ and $1.0 \%)$, $\mathrm{KH}_{2} \mathrm{PO}_{4}(0.5$ and $1.0 \%), \mathrm{KCl}(50$ and 100 $\mathrm{ppm}), \mathrm{GA}_{3}$ (50 and $100 \mathrm{ppm}$ ) and cytokinin $(50$ and $100 \mathrm{ppm})$ and hydro-priming (priming with water) were used for priming treatment. Un-primed seeds were used as control. In all the priming treatments, seeds were primed for 2 hours priming duration. After priming, the seeds were dried under shade and immediately used for sowing. The field research trial consisted of twelve priming treatments and conducted in Randomized complete block design with four replications. The crop was sown on raised bed with 2 rows per bed with spacing of $67.5 \mathrm{~cm}$. The recommended fertilizer dose of $32 \mathrm{~kg} \mathrm{~N}$ and $80 \mathrm{~kg} \mathrm{P}_{2} \mathrm{O}_{5} \mathrm{ha}^{-1}$ was applied as urea (46 $\% \mathrm{~N})$ and single superphosphate $\left(16 \% \mathrm{P}_{2} \mathrm{O}_{5}\right)$ before sowing soybean. Stomp 30 EC (pendimethalin) at 1.5 litres ha $^{-1}$ was applied as pre-emergence, followed by one hand weeding at 40 days after sowing to control weeds.

Using five selected plants from each plot, number of pods per plant, number of seeds per pod, and 100- seeds were recorded. Before threshing the total weight of harvested crop plants from the net plot area was considered as the biological yield. The recorded biological yield was expressed in $\mathrm{kg}$ $\mathrm{ha}^{-1}$. After sun drying for a few days, the harvested crop from respective net plot was threshed with thresher. Seed yield was recorded and expressed as $\mathrm{kg} \mathrm{ha}^{-1}$. The straw yield was obtained after deducting the seed yield from the total above ground biological yield (bundle weight before threshing) for each plot. HI was calculated by dividing economic (seed) yield by the total biological (seed + straw) yield and expressed as percentage.

$$
\mathrm{HI}(\%)=\frac{\text { Economic yield }}{\text { Biological yield }}
$$

\section{Results and Discussion}

\section{Yield attributes}

\section{Number of pods per plant}

Number of pods per plant is an important attribute which is highly co-related to the final seed yield. The higher the number of pods, the higher will be the yield. The data regarding the number of pods per plant are presented in Table 1. The number of pods per plant was found to be significantly influenced by priming treatments during both the years. In 2015, number of pods per plant was significantly higher with $100 \mathrm{ppm} \quad \mathrm{GA}_{3}$ treated seeds i.e. 73.9 pods per plant as compared to other treatments. Treatment 100 ppm cytokinin recorded significantly higher pod number per plant (67.6 pods per plant) which was statistically similar in results with 50 ppm $\mathrm{GA}_{3}$ (65.4 pods per plant) and 50 ppm cytokinin i.e. 64.9 pods per plant, respectively. During 2016, similar trend was observed significantly higher number of pods per plant was recorded with $100 \mathrm{ppm} \mathrm{GA}_{3}$ treated seeds (78.1 pods per plant). Other treatments like $100 \mathrm{ppm}$ cytokinin recorded statistically similar results with $50 \mathrm{ppm} \mathrm{GA}_{3}$ 
and 50 ppm cytokinin. When 100 ppm $\mathrm{GA}_{3}$ was used to treat seed it recorded increase in number of seeds by $7.2 \%$ than 100 ppm cytokinin treated seeds. This increase in number of pods per plant which might be due to more dry matter accumulation and LAI of the crop which increased the photosynthetic efficiency and assimilates production for pods per plant. Significantly 45 and $43 \%$ increase in pods per plant was recorded when the soybean seeds were treated with 100 ppm $\mathrm{GA}_{3}$ than control (50.9 and 54.4) in both the two years. Mazed et al., (2015) also reported that Seed priming with $\mathrm{GA}_{3}$ exhibited significant differences with respect of number of pods per plant.

\section{Number of seeds per pod}

Number of seeds per pod is an important yield attributing character that influences the final seed yield. More number of seeds per pod will result in more number of total seeds per plant.

The number of seeds per pod did not differ significantly with different priming treatments (Table 1). During 2015, maximum number of seeds per pod was recorded with $100 \mathrm{ppm}$ $\mathrm{GA}_{3}$ treated seeds (2.60 seeds per pod). Other treatments 100 ppm cytokinin $(2.35$ seeds per pod), 50 ppm $\mathrm{GA}_{3}$ (2.30 seeds per pod) and $50 \mathrm{ppm}$ cytokinin (2.30 seeds per pod) also recorded comparative higher number of seeds per pod than control.

In 2016, the data recorded on seeds per pod shows that comparative higher number of seeds per pod was recorded with $100 \mathrm{ppm}$ $\mathrm{GA}_{3}$ i.e. 2.65 seeds per pod as compared to control. $\mathrm{GA}_{3}$ treated seeds $(100 \mathrm{ppm})$ recorded 10.6 and $10.4 \%$ increase in seeds number per pod than $100 \mathrm{ppm}$ cytokinin treated seeds in both the years. Mazed et al., (2015) observed that Number of seeds per pod of chickpea differed significantly due to seed priming with $\mathrm{GA}_{3}$.

\section{0-seed weight}

100 seed weight of a crop is positively correlated with final seed. It is evident from the data (Table 1) that different priming treatments had a non-significant effect on 100 seed weight in 2015 and 2016 respectively. Data showed that in 2015, $11.8 \mathrm{~g}$ weight of 100 seeds was recorded with 100 ppm $\mathrm{GA}_{3}$ treated seeds which were comparative higher than other treatments. Same as during 2016, comparative higher 100 seed weight was recorded i.e. $10.9 \mathrm{~g}$ with treatment $\mathrm{GA}_{3}$ at 100 ppm. In the year, 42 and $35 \%$ increase in 100 seeds weight was recorded when the seeds were pre-soaked with $100 \mathrm{ppm} \mathrm{GA}_{3}$ than control which recorded 8.27 and $8.05 \mathrm{~g}$ seed weight in 2015 and 2016, respectively.

\section{Biological yield}

The data on biological yield as presented in Table 2 and Figure 1 shows that biological yield was significantly higher in $\mathrm{GA}_{3}$ treated seeds@ @ 100 ppm in both the two years (5886 and $6014 \mathrm{~kg} \mathrm{ha}^{-1}$ ) which was statistically similar with 100 ppm Cytokinin (5732 and $5839 \mathrm{~kg} \mathrm{ha}^{-1}$ ) but significantly better than other treatments during the two years, respectively.

In 2015, when the seeds primed with $\mathrm{GA}_{3}$ and Cytokinin at the rate of $50 \mathrm{ppm}$ recorded statistically similar result with each other and recorded 5631 and $5632 \mathrm{~kg} \mathrm{ha}^{-1}$ biological yield respectively. In 2016, treatments viz. 50 ppm $\mathrm{GA}_{3}, 50 \mathrm{ppm}$ cytokinin, $50 \mathrm{ppm} \mathrm{KCl}$, $100 \mathrm{ppm} \mathrm{KCl}$ and $0.1 \% \mathrm{KH}_{2} \mathrm{PO}_{4}$ recorded statistically similar with each other. Cytokinin applied at $50 \mathrm{ppm}$ recorded $15.6 \%$ higher biological yield as compared to control in 2016. When dry seeds were used as control significantly lower biological yield was recorded during both the years (4935 and $4932 \mathrm{~kg} \mathrm{ha}^{-1}$ ) respectively. This increase in biological yield with respect to priming 
treatments might be due to more plant height and dry matter accumulation by the soybean crop. Mazed et al., (2015) found similar results with different concentrations of $\mathrm{GA}_{3}$. Seed priming with $\mathrm{GA}_{3}$ recorded significant results in production of biological yield of chickpea crop. The highest biological yield was obtained (4388 kg ha ${ }^{-1}$ ) when the seeds were pre-soaked in $225 \mathrm{ppm} \mathrm{GA}_{3}$, which statistically similar (4132 $\mathrm{kg} \mathrm{ha}^{-1}$ ) to $300 \mathrm{ppm}$ $\mathrm{GA}_{3}$. The lowest biological yield $(2503 \mathrm{Kg}$ $\mathrm{ha}^{-1}$ ) was found in hydro-primed chickpea seeds.

\section{Seed yield}

Seed yield is an important parameter for judging the efficiency of the applied treatments. Seed yield, though a varietal characteristic yet, is altered through management of many agronomic practices. It is determined by various physiological processes at plant level such as dry matter accumulation, leaf area development, photosynthesis and translocation. Growth regulators are known to significantly affect the physiological processes which determine the final crop yield. The analysis of field observation presented in Table 2 and Figure 2 , showed that significantly higher seed yield was recorded in both the years when the seeds were pre-soaked in $\mathrm{GA}_{3}$ at $100 \mathrm{ppm}$. During 2015, significantly higher seed yield was recorded with treatment 100 ppm $\mathrm{GA}_{3}$ i.e. $2442 \mathrm{~kg} \mathrm{ha}^{-1}$ which was statistically similar with other treatment $100 \mathrm{ppm}$ cytokinin (2374 $\left.\mathrm{kg} \mathrm{ha}^{-1}\right), 50$ ppm GA 3 (2329 $\left.\mathrm{kg} \mathrm{ha}^{-1}\right)$ and 50 ppm cytokinin (2329 $\left.\mathrm{kg} \mathrm{ha}^{-1}\right)$, respectively. Statistically at par seed yield was recorded when the seeds were treated with 50 and 100 ppm KCl (2248 and $\left.2250 \mathrm{~kg} \mathrm{ha}^{-1}\right), 0.5$ and 1.0 $\% \mathrm{KH}_{2} \mathrm{PO}_{4}\left(2224\right.$ and $\left.2239 \mathrm{~kg} \mathrm{ha}^{-1}\right), 0.5$ and $1.0 \% \mathrm{KNO}_{3}\left(2138\right.$ and $2192 \mathrm{~kg} \mathrm{ha}^{-1}$ ) and water treated seeds $\left(2122 \mathrm{~kg} \mathrm{ha}^{-1}\right)$ as compared to control.

Table.1 Effect of seed priming on yield attributes of bed planted soybean

\begin{tabular}{|c|c|c|c|c|c|c|}
\hline \multirow[t]{2}{*}{ Seed priming } & \multicolumn{2}{|c|}{ Pods plant $^{-1}$} & \multicolumn{2}{|c|}{ Seeds pod $^{-1}$} & \multicolumn{2}{|c|}{ 100-seed weight (g) } \\
\hline & 2015 & 2016 & 2015 & 2016 & 2015 & 2016 \\
\hline Control & 50.9 & 54.4 & 2.02 & 2.12 & 8.27 & 8.05 \\
\hline Water & 53.7 & 57.6 & 2.12 & 2.15 & 8.37 & 8.47 \\
\hline $\mathrm{KNO}_{3}(0.5 \%)$ & 54.6 & 58.7 & 2.15 & 2.25 & 8.50 & 8.60 \\
\hline $\mathrm{KNO}_{3}(1.0 \%)$ & 55.3 & 60.5 & 2.12 & 2.25 & 9.00 & 8.85 \\
\hline $\mathrm{KH}_{2} \mathrm{PO}_{4}(0.5 \%)$ & 55.8 & 61.3 & 2.20 & 2.20 & 9.20 & 8.92 \\
\hline $\mathrm{KH}_{2} \mathrm{PO}_{4}(1.0 \%)$ & 56.2 & 62.2 & 2.20 & 2.25 & 9.27 & 9.12 \\
\hline $\mathrm{KCl}(50 \mathrm{ppm})$ & 56.5 & 63.1 & 2.25 & 2.25 & 9.27 & 8.95 \\
\hline $\mathrm{KCl}(100 \mathrm{ppm})$ & 59.8 & 64.9 & 2.25 & 2.30 & 9.37 & 9.07 \\
\hline $\mathrm{GA}_{3}(50 \mathrm{ppm})$ & 65.4 & 72.1 & 2.30 & 2.40 & 10.3 & 9.80 \\
\hline $\mathrm{GA}_{3}(100 \mathrm{ppm})$ & 73.9 & 78.1 & 2.60 & 2.65 & 11.8 & 10.9 \\
\hline Cytokinin (50 ppm) & 64.9 & 70.2 & 2.30 & 2.35 & 9.90 & 9.07 \\
\hline Cytokinin (100 ppm) & 67.6 & 72.8 & 2.35 & 2.40 & 10.1 & 10.3 \\
\hline $\mathrm{CD}(\mathrm{p}=0.05)$ & 5.79 & 5.04 & $\mathrm{NS}$ & NS & NS & NS \\
\hline
\end{tabular}


Table.2 Effect of seed priming on yield and harvest index of bed planted soybean

\begin{tabular}{|c|c|c|c|c|c|c|c|c|c|}
\hline \multirow[t]{2}{*}{ Seed priming } & \multicolumn{2}{|c|}{$\begin{array}{c}\text { Biological } \\
\text { yield }\left(\mathrm{kg} \mathrm{ha}^{-1}\right)\end{array}$} & \multicolumn{2}{|c|}{$\begin{array}{l}\text { Seed yield } \\
\left(\mathrm{kg} \mathrm{ha}^{-1}\right)\end{array}$} & \multirow{2}{*}{$\begin{array}{c}\text { Pooled } \\
\text { seed } \\
\text { yield }\end{array}$} & \multicolumn{2}{|c|}{$\begin{array}{c}\text { Straw yield } \\
\left(\mathrm{kg} \mathrm{ha}^{-1}\right)\end{array}$} & \multicolumn{2}{|c|}{$\begin{array}{c}\text { Harvest } \\
\text { index }(\%)\end{array}$} \\
\hline & 2015 & 2016 & 2015 & 2016 & & 2015 & 2016 & 2015 & 2016 \\
\hline Control & 4935 & 4932 & 1891 & 1908 & 1899 & 3044 & 3024 & 38.3 & 38.9 \\
\hline Water & 5196 & 5162 & 2122 & 2116 & 2119 & 3074 & 3046 & 40.8 & 41.0 \\
\hline $\mathrm{KNO}_{3} \mathrm{C}$ & 5233 & 5248 & 2138 & 2159 & 2148 & 3095 & 3089 & 40.9 & 41.1 \\
\hline $\mathrm{KNO}_{3}(1.0 \%)$ & 5354 & 5284 & 2192 & 2176 & 2184 & 3162 & 3108 & 41.0 & 41.2 \\
\hline $\mathrm{KH}_{2} \mathrm{PO}_{4}(0.5 \%)$ & 5426 & 5399 & 2224 & 2212 & 2217 & 3202 & 3187 & 41.0 & 41.0 \\
\hline $\mathrm{KH}_{2} \mathrm{PO}_{4}(1.0 \%)$ & 5448 & 5487 & 2239 & 2251 & 2245 & 3209 & 3236 & 41.1 & 41.0 \\
\hline $\mathrm{KCl}(50 \mathrm{ppm})$ & 5469 & 5501 & 2248 & 2275 & 2261 & 3220 & 3225 & 41.1 & 41.4 \\
\hline $\mathrm{KCl}(100 \mathrm{ppm})$ & 5469 & 5613 & 2250 & 2320 & 2285 & 3219 & 3293 & 41.2 & 41.3 \\
\hline $\mathrm{GA}_{3}(50 \mathrm{ppm})$ & 5631 & 5701 & 2329 & 2370 & 2349 & 3302 & 3331 & 41.4 & 41.6 \\
\hline $\mathrm{GA}_{3}(100 \mathrm{ppm})$ & 5886 & 6014 & 2442 & 2521 & 2481 & 3444 & 3493 & 41.5 & 42.0 \\
\hline Cytokinin $(50 \mathrm{ppm})$ & 5632 & 5705 & 2329 & 2373 & 2350 & 3303 & 3332 & 41.4 & 41.6 \\
\hline $\begin{array}{l}\text { Cytokinin (100 } \\
\text { ppm) }\end{array}$ & 5732 & 5839 & 2374 & 2445 & 2409 & 3358 & 3393 & 41.4 & 41.9 \\
\hline $\mathrm{CD}(\mathrm{p}=0.05)$ & 160 & 235 & 149 & 160 & 113 & 226 & 287 & NS & NS \\
\hline
\end{tabular}

Fig.1 Effect of seed priming on Biological yield $\left(\mathrm{kg} \mathrm{ha}^{-1}\right)$ of bed planted soybean

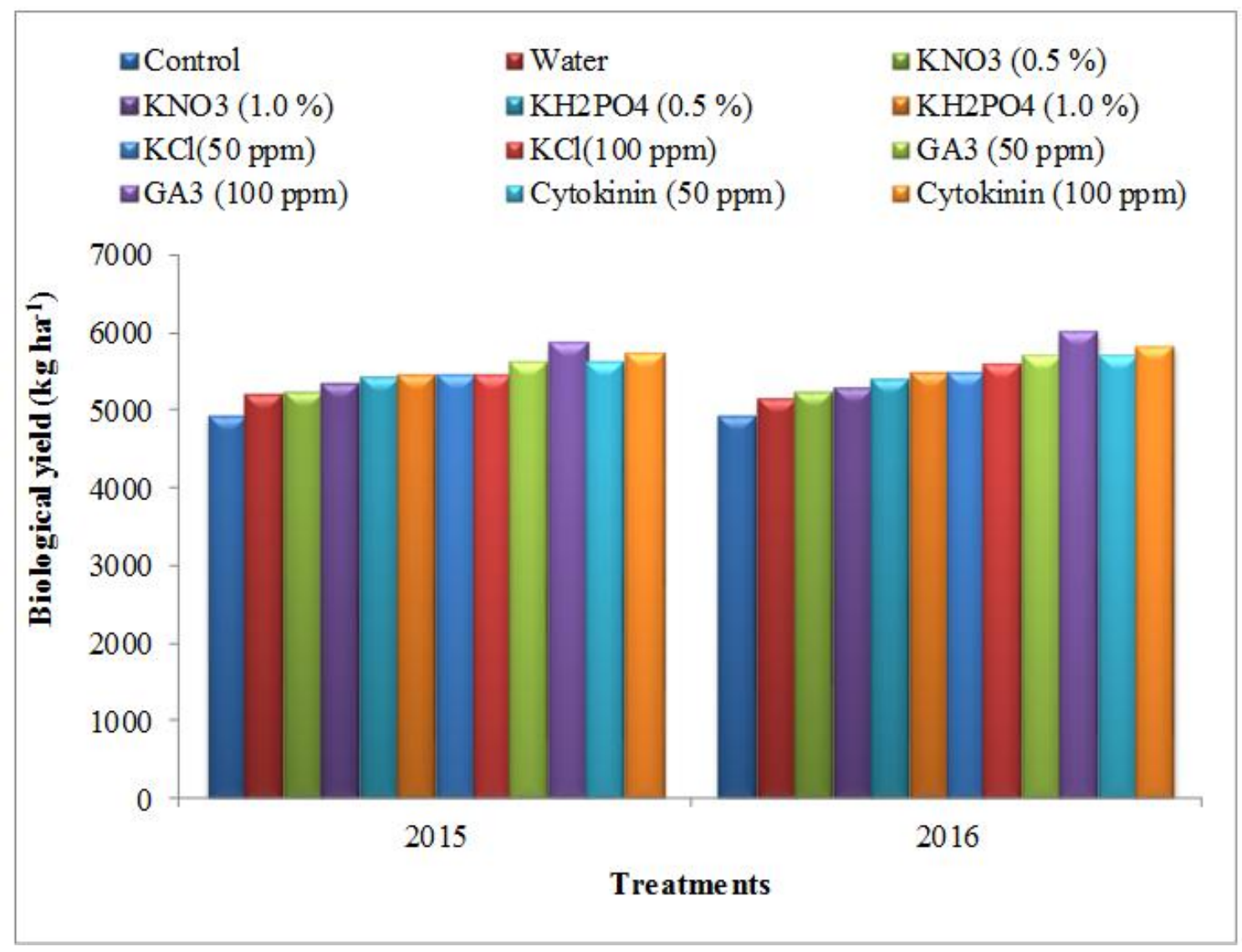


Fig.2 Effect of seed priming on seed yield $\left(\mathrm{kg} \mathrm{ha}^{-1}\right)$ of bed planted soybean

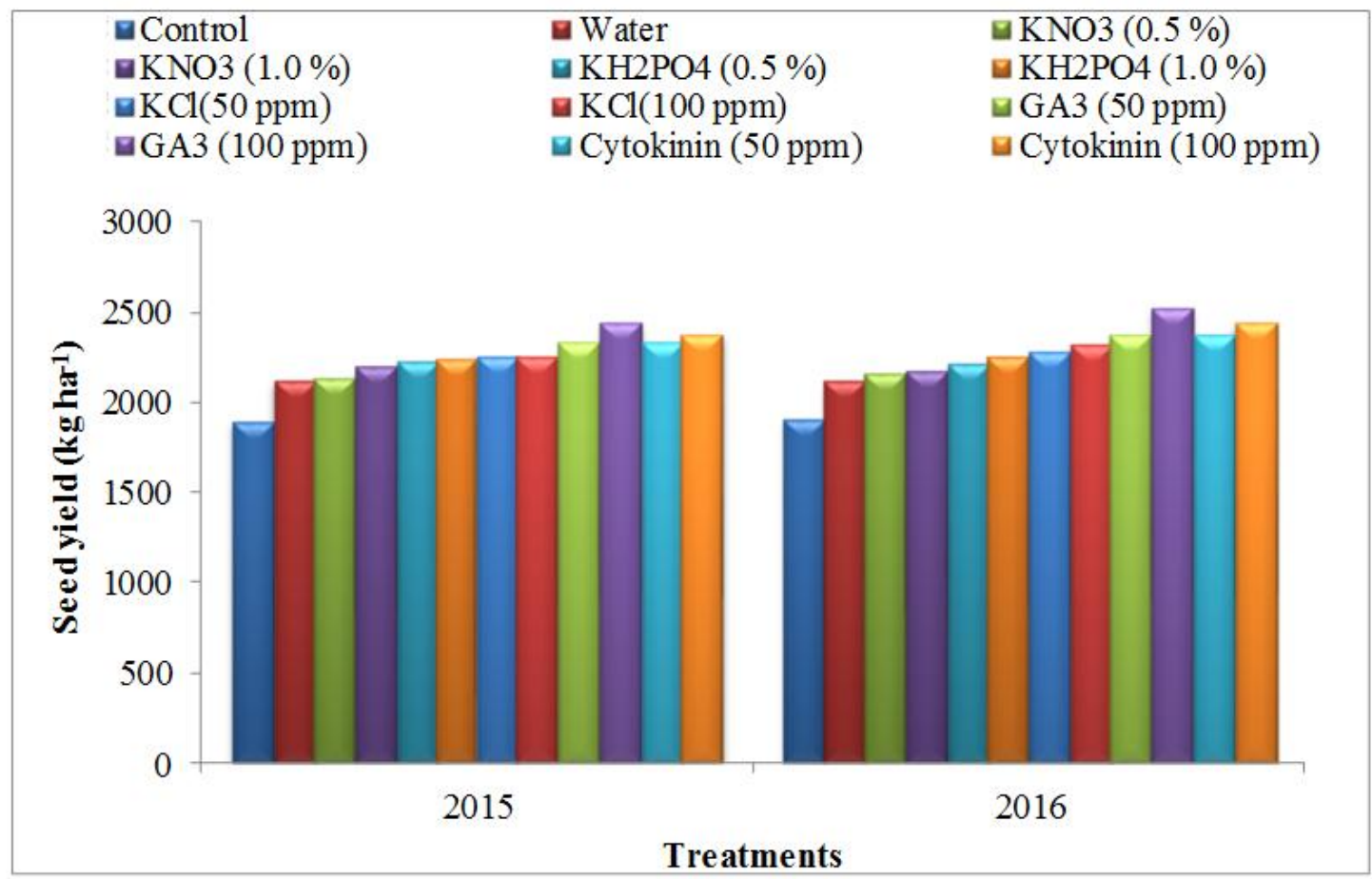

Fig.3 Effect of seed priming on straw yield $\left(\mathrm{kg} \mathrm{ha}^{-1}\right)$ of bed planted soybean

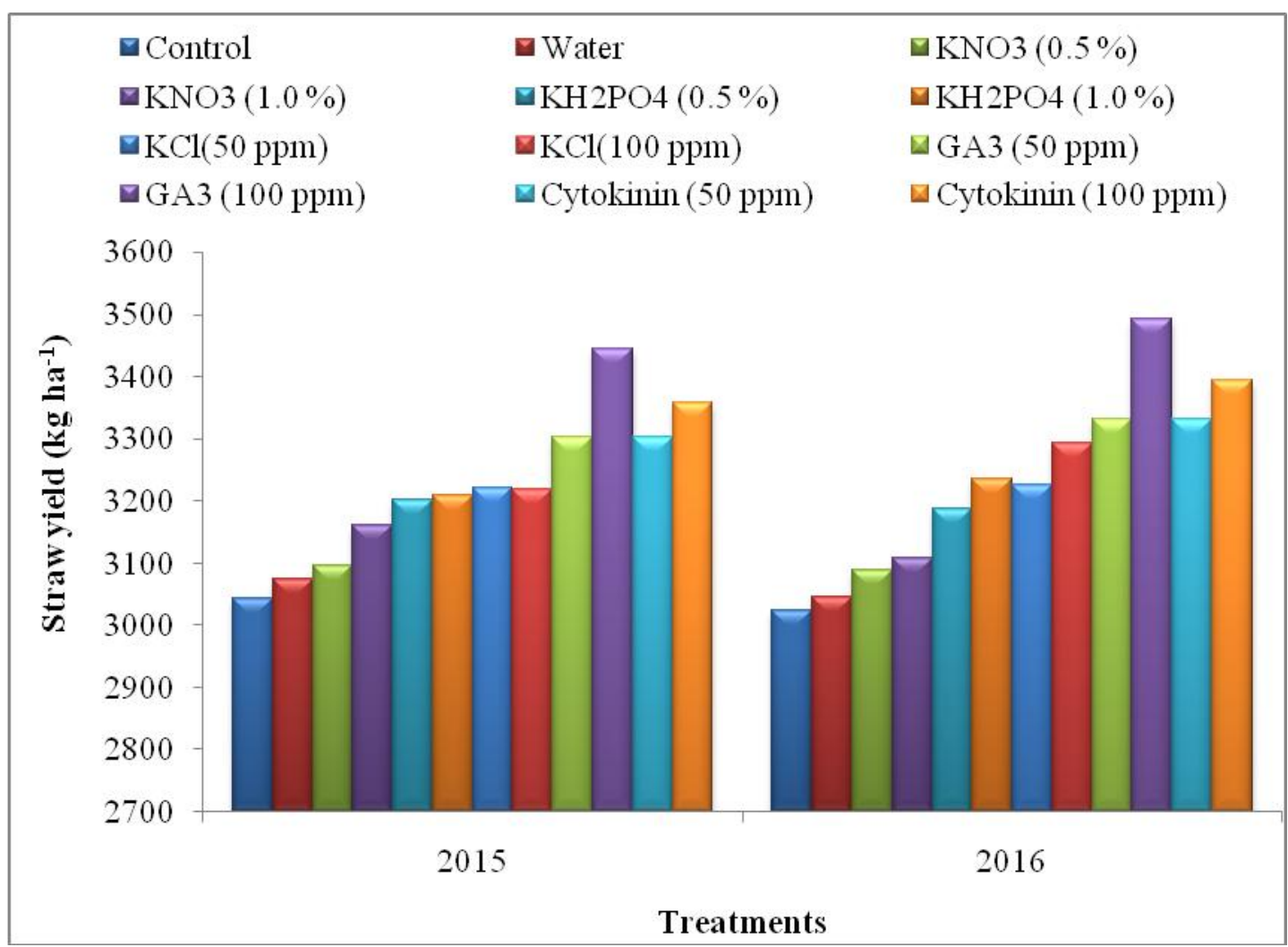


Fig.4 Effect of seed priming on harvest index (\%) of bed planted soybean

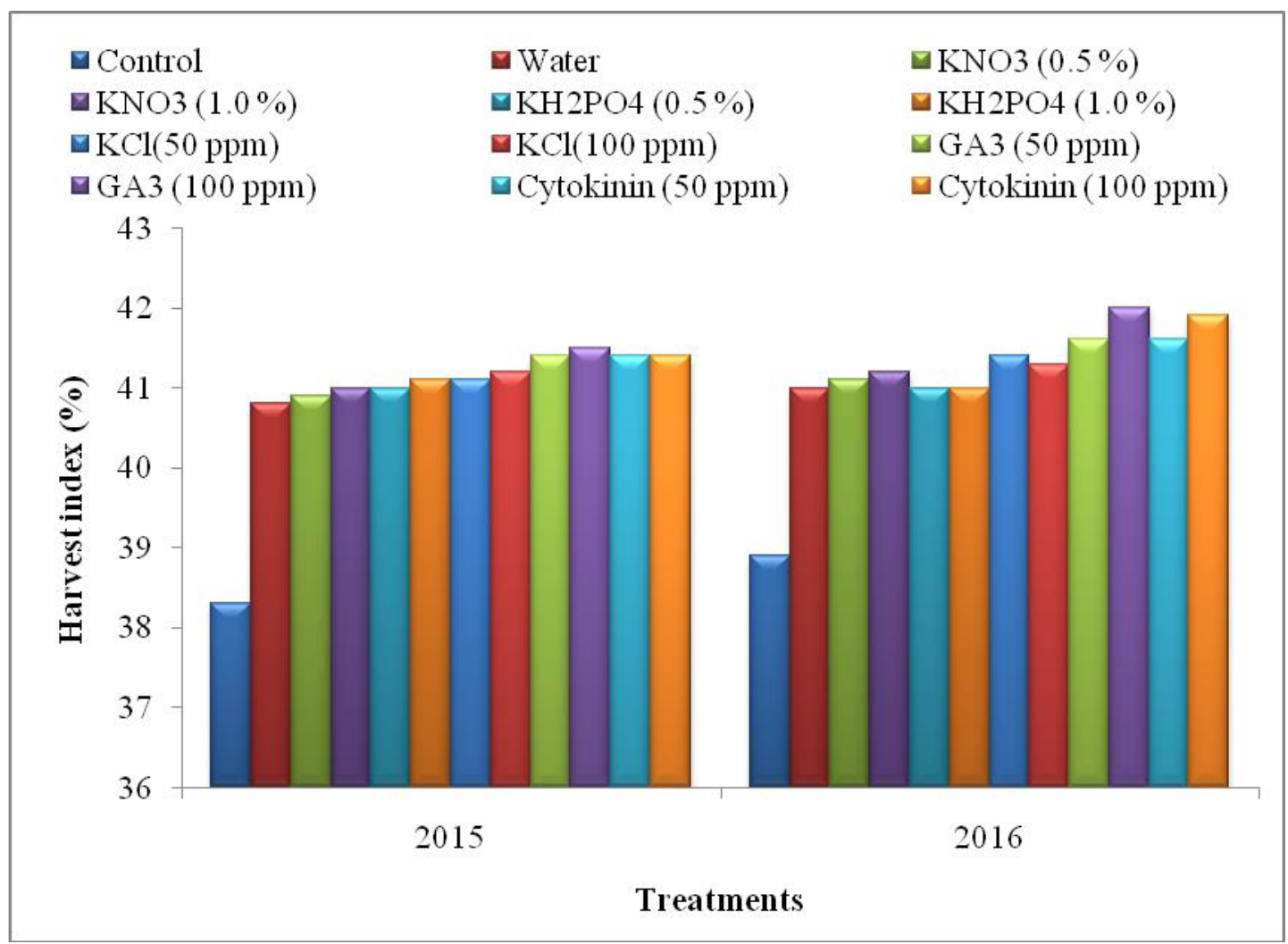

During 2016, when the seeds were treated with 100 ppm $\mathrm{GA}_{3}$ it recorded $32.1 \%$ higher seed yield as compared to control and recorded statistically at par results with 100 ppm cytokinin $\left(2445 \mathrm{~kg} \mathrm{ha}^{-1}\right), 50 \mathrm{ppm} \mathrm{GA}$ $\left(2370 \mathrm{~kg} \mathrm{ha}^{-1}\right)$ and $50 \mathrm{ppm}$ cytokinin $(2373 \mathrm{~kg}$ $\left.\mathrm{ha}^{-1}\right)$, respectively. Other treatment in which seeds treated with 50 and $100 \mathrm{ppm} \mathrm{KCl}$ recorded 2275 and $2320 \mathrm{~kg} \mathrm{ha}^{-1}$ seed yield which was statistically similar with 0.5 and $1.0 \% \mathrm{KH}_{2} \mathrm{PO}_{4}$ i.e. 2212 and $2251 \mathrm{~kg} \mathrm{ha}^{-1}$ ) and $1.0 \% \mathrm{KNO}_{3}\left(2176 \mathrm{~kg} \mathrm{ha}^{-1}\right)$ as compared to control and water treated seeds.

When seeds were primed with 100 ppm $\mathrm{GA}_{3}$ it recorded $2.8 \%$ and $3.1 \%$ higher seed yield as compared to $100 \mathrm{ppm}$ cytokinin in both the two years. Maximum seed yield in $\mathrm{GA}_{3}$ was registered due to higher number of pods per plant, more seeds per pod and 100 seed weight. This increase in yield attributing characters and final seed yield with $\mathrm{GA}_{3}$ might be due to enhanced enzymatic action. Enzymes such as amylases, proteases and lipases play vital roles in the early growth and development of embryo. Any increase in the activity of these enzymes may result in early vigorous growth and good crop establishment which in turn improve the yield of the crop. Khan et al., (2002) also reported that $\mathrm{GA}_{3}$ improved the seed yield by the efficient exploitation of photosynthates and metabolic enhancement. Mazed et al., (2015) found that when chickpea was primed with $225 \mathrm{ppm}$ $\mathrm{GA}_{3}$, it recorded significantly maximum seed yield.

Pooled analysis of seed yield is presented in Table 2. The data shows that significantly higher seed yield was recorded with treatment of $100 \mathrm{ppm} \mathrm{GA}_{3}\left(2481 \mathrm{~kg} \mathrm{ha}^{-1}\right)$ as compared to other which recorded statistically at par result with 100 ppm Cytokinin (2409 $\mathrm{kg} \mathrm{ha}^{-1}$ ). 100 ppm $\mathrm{GA}_{3}$ recorded increase in seed yield 
by $30.6 \%$ as compared to control. Same as $100 \mathrm{ppm}$ cytokinin treatment recorded $26.8 \%$ increase in seed yield than control.

\section{Straw Yield}

Straw yield is directly affected by growth parameters. The data regarding straw yield exhibited that significantly higher straw yield was recorded when the soybean seeds were treated with 100 ppm $\mathrm{GA}_{3}$ during both the years (Table 2 and Figure 3). In 2015, significantly higher straw yield was recorded with 100 ppm $\mathrm{GA}_{3}$ (3444 $\mathrm{kg} \mathrm{ha}^{-1}$ ) which recorded statistically similar results with cytokinin@100 ppm (3358 kg ha $\left.{ }^{-1}\right), 50$ ppm cytokinin $\left(3303 \mathrm{~kg} \mathrm{ha}^{-1}\right), \mathrm{GA}_{3}$ at $50 \mathrm{ppm}$ (3302 $\mathrm{kg} \mathrm{ha}^{-1}$ ) and $100 \mathrm{ppm} \mathrm{KCl}(3219 \mathrm{~kg}$ $\mathrm{ha}^{-1}$ ). When seeds were treated with $100 \mathrm{ppm}$ $\mathrm{GA}_{3}$, straw yield was improved to the terms of $2.56 \%$ as compared to 100 ppm cytokinin.

Similar trend was observed in 2016, significantly higher straw yield was obtained when the seeds were pre-soaked with 100 ppm $\mathrm{GA}_{3}$ (3493 $\mathrm{kg} \mathrm{ha}{ }^{-1}$ ) which was at statistically at par with cytokinin @ 100 ppm (3393 kg ha ${ }^{-1}$ ), 50 ppm cytokinin (3332 kg $\left.\mathrm{ha}^{-1}\right), \mathrm{GA}_{3}$ at $50 \mathrm{ppm}\left(3331 \mathrm{~kg} \mathrm{ha}^{-1}\right), 50 \mathrm{ppm}$ $\mathrm{KCl}\left(3225 \mathrm{~kg} \mathrm{ha}^{-1}\right), 100 \mathrm{ppm} \mathrm{KCl}(3293 \mathrm{~kg}$ $\left.\mathrm{ha}^{-1}\right)$ and $1.0 \% \mathrm{KH}_{2} \mathrm{PO}_{4}\left(3236 \mathrm{~kg} \mathrm{ha}^{-1}\right)$.

Control treatment i.e. dry seeds recorded lower straw yield during both the years i.e. 3044 and $3024 \mathrm{~kg} \mathrm{ha}^{-1}$, respectively. $100 \mathrm{ppm}$ $\mathrm{GA}_{3}$ recorded a significant increase of 13.1 and $15.5 \%$ in straw yield as compared to control or dry seeds during the two years of field study, respectively. Considerable increase in straw yield might be attributed to improvement in growth parameters like plant height, dry matter and LAI. Mazed et al., (2015) reported that highest straw yield (2701 $\mathrm{kg} \mathrm{ha}{ }^{-1}$ ) was observed with $225 \mathrm{ppm} \mathrm{GA}_{3}$, whereas the lowest straw yield (1522 $\mathrm{kg} \mathrm{ha}^{-1}$ ) was found in $300 \mathrm{ppm} \mathrm{GA}_{3}$.

\section{Harvest index}

Harvest index (HI) is the measure of partitioning efficiency of biomass to the economic part of the crop i.e. seed yield in soybean. The data pertaining to $\mathrm{HI}$ are presented in Table 2 and Figure 4. Seed priming recorded non-significant effect on $\mathrm{HI}$ of the soybean crop in both the two years. Data presented in the table shows that $41.5 \%$ HI was recorded when seeds were treated with 100 ppm $\mathrm{GA}_{3}$ which was comparative better in result as compared to other treatments.

During 2016, a non-significant result was observed with different seed priming treatments. Results shows that seeds treated with 100 ppm $\mathrm{GA}_{3}$ recorded $42.0 \% \mathrm{HI}$ which was comparative higher than other treatments. Control treatment or dry seeds recorded lesser values of HI i.e. 38.3 and $38.9 \%$ during 2015 and 2016, respectively. $\mathrm{GA}_{3}$ treated seeds at $100 \mathrm{ppm}$ recorded increase in HI by 8.3 and $7.9 \%$ as compared to control treatment during both the two years. Mazed et al., (2015) observed that when chickpea seeds were treated with $225 \mathrm{ppm} \mathrm{GA}_{3}$ it recorded significantly utmost harvest index than 75, 150 and $300 \mathrm{ppm} \mathrm{GA}_{3}$. From this field study we can concluded that seed priming provide better good stand establishment under a wide range of environmental conditions. Results revealed that seed priming with 100 ppm $\mathrm{GA}_{3}$ provide significantly higher yield and yield related attributes as compared to other seed priming treatments.

\section{Acknowledgements}

I am highly indebted to Punjab Agricultural University, Ludhiana for providing the necessary research and laboratory facilities for conducting the research and support provided by University Grants Commission in the form of Rajiv Gandhi National Fellowship 
during the tenure is gratefully acknowledged.

\section{References}

Ashraf, M. and Foolad, M.R. 2005. Presowing seed treatment-a shotgun approach to improve germination, plant growth, and crop yield under saline and non-saline conditions. Advan. Agron, 88: 223-276.

Farooq, M., Aziz, T., Basra, S. M. A., Cheema, M.A. and Rehman, H. 2008. Chilling tolerance in hybrid maize induced by seed priming with salicylic acid. J. Agro.Crop. Sci, 6:161-168

Harris, D., Joshi, A., Khan, P. A., Gothkar, P. and Sodhi, P. S. 2004. On-farm seed priming in semi-arid agriculture, development and evoluation in maize, rice and chickpea in India using participatory methods. Exp. Agric, 35: 15-29.

Khan, H., Malik, A. M., Saleem, F., Mumtaz, A., Cheema, M. A. and Ahmad, A.
2002. Effect of different seeding times and seed rates on the growth yield and quality of Rice bean. Int. J. Agric. Bio, 1560: 104-06.

Mazed, H. E., Khairul, Haque., Israt, J., Ashraful, I. P. and Abu, H. Md. 2015. Effect of seed priming on growth, yield and seed quality of chickpea (BARI chhola-6). Int. J. Multidisciplinary. Res. Dev, 2: 142-47.

Musa, A. M., Harris, D., Johansen, C. and Kumar, J. 2001. Short duration chickpea to replace fellow after AMAN rice: The role of on-farm seed priming in the high arid tract of Bangladesh. Expl. Agric, 37: 509-521.

Rashid, A., Harris, D., Hollington, P. and Ali, S. 2004. On-farm seed priming reduces yield losses of mung bean (Vigna indiata) associated with mung bean yellow mosaic virus in NWFP of Pakistan. Crop. Protect, 23: 1119-1124.

\section{How to cite this article:}

Rupinder Kaur Jassal, Harmeet Singh and Jasjit Singh Kang. 2017. Yield and Yield Attributes of Soybean (Glycine $\max$ L.) as Affected by Seed Priming. Int.J.Curr.Microbiol.App.Sci. 6(12): 4285-4293. doi: https://doi.org/10.20546/ijcmas.2017.612.492 